\title{
It's Your Job to Save Me: The Union of Canadian Correctional Officers and the Death of Ashley Smith
}

Gillian Balfour

\begin{abstract}
The death of Ashley Smith represents the first time in Canadian legal history that correctional officers were criminally charged in the death of a prisoner under the care of the state. In response to these unprecedented charges, the Union of Canadian Correctional Officers (UCCO) mounted a highly public campaign in defense of the officers. In this article, I review UCCO's media statements following Smith's death, submissions to various government review committees, and the current Global Agreement between UCCO and Correctional Service Canada (CSC) regarding federally sentenced women. I suggest these narratives work to reproduce administrative segregation as necessary to manage "troubled young women" who are constituted as an unsafe working condition for officers. I highlight the failure of UCCO to influence government policy, unlike the effective success of unions in the United States, and I challenge the place of UCCO in Canada's trade union movement.
\end{abstract}

Keywords: correctional officers, death in custody, segregation, women prisoners, trade unions

\section{Résumé}

Le décès d'Ashley Smith est le premier de l'histoire judiciaire canadienne à l'égard duquel des agents correctionnels ont été formellement accusés de la mort d'un détenu aux soins de l'État. En réponse à ces accusations sans précédent, le Syndicat des agents correctionnels du Canada (SACC), se portant à la défense des agents, a mené une campagne abondamment publicisée. Dans cet article, j’examinerai les déclarations aux médias et les soumissions à divers comités d'examen gouvernementaux faites par le SACC après la mort d'Ashley Smith ainsi que l'entente globale actuelle entre le Service correctionnel Canada (SCC) et le SACC relativement aux détenues sous responsabilité fédérale. Je soutiens que ces discours contribuent à reproduire le caractère nécessaire de l'isolement préventif dans la gestion de « jeunes femmes perturbées " perçues comme étant une condition de travail non sécuritaire pour les agents. Je souligne le fait que, contrairement aux syndicats américains, le SACC n’a pas réussi à influencer les politiques gouvernementales. Enfin, je remets en question la légitimité du SACC au sein du mouvement des organisations syndicales canadiennes.

Mots clés : agents correctionnels, décès durant la détention, isolement, femmes détenues, organisations syndicales

Canadian Journal of Law and Society / Revue Canadienne Droit et Société, 2017,

Volume 32, no. 2, pp. 209-228. doi:10.1017/cls.2017.13 


\section{Introduction}

It's no accident that UCCO-SACC-CSN is known as one of the most militant unions in the federal public service. We have fought with pride, solidarity and dignity to build a strong union and to achieve important improvements in our workplace. (Kevin Grabowsky, National President, Union of Canadian Correctional Officers)

As this special issue illuminates, the death of Ashley Smith has evoked a range of analytical approaches to the socio-legal analysis of the conditions of confinement in Canada's federal prisons for women. This article, however, is unique in that it addresses the paradox of trade unionists who seem to unreflexively carry out the activities of the carceral state. One of the first (and only) Canadian publications on the classed structure of prison guard labour, is Desmond Ellis's (1979) treatise on the introduction of therapeutic managerialism into the Canadian Penitentiary Service as a strategy to diffuse the intraclass conflicts (prison riots) between the "carceral proletariat" of prison guards and prisoners (44). Since then, there have been no published Canadian empirical studies of prison guards as waged workers. This contrasts with the vibrant histories of prison labour and prisoner organizing in the United States (Blankenship 2005; Thompson 2011; 2016; Zinn 2003; Zimmer and Jacobs 1981). In more contemporary terms-as will be discussed later in this article-Joshua Page (2011) and James Kilgore (2013) document the ascendancy of professional prison officer associations in the United States that have been emboldened by tough-on-crime conservative politicians, as well as the impacts of neo-liberal criminalization of the working class. I believe it is important for us to consider the US experience of trade unions as part of the carceral state because, as Wacquant asserts, "the global firestorm of law and order inspired by the United States has raged far and wide, even as it [takes] different paths and forms in the different countries it [strikes]" $(2014,72)$. Canada's own neoliberal state has triggered the fragmentation of labour, where "the working class itself faces criminalization" (Kilgore 2013, 360). Well-paying jobs-such as those of correctional officers-are fiercely defended, despite documented evidence of human rights abuses in their places of employment. I suggest, however, that these important labour studies do not attend to the gendered endangerment of women prisoners such as Ashley Smith.

This article explores a relatively unknown aspect of Canada's federal correctional system: the Union of Canadian Correctional Officers (UCCO-SACC-CSN) ${ }^{1}$. The certification of the UCCO took place in 1999, after a referendum to leave the Public Service Alliance of Canada. Today the UCCO speaks on behalf of 8,200 correctional staff working in 40 institutions and is affiliated with the Confédération des syndicats nationaux in Quebec - a central labour body of trade unions. In this article, I do not engage with the sociological or psychological literatures of correctional officers' occupational experiences. Rather, I consider the role of the UCCO

Union of Canadian Correctional Officers - Syndicat des agents correctionnels du Canada Confédération des syndicats nationaux http://ucco-sacc-csn.ca/wp-content/uploads/2016/08/ UCCO-SACC-CSN-Constitution-EN-2016.pdf 
as a trade union in reproducing the carceral state through gendered discourses of worker endangerment and distress. I explore how UCCO opposed the implementation of Creating Choices (Government of Canada 1990), and the recommendations of the Arbour Commission of Inquiry (1996). I examine the various narratives that appear throughout the UCCO newsletters, in statements to the media following Smith's death, as well as in their submissions to government review committees regarding federally sentenced women. I suggest these texts work to re-entrench the "unmanageable dangerous girl" as a threat to public safety through a discourse of workers' rights. These texts disembody and reframe Ashley Smith's suffering as an unsafe working condition that exposed officers to physical and psychological distress and obfuscate Smith's rights as a prisoner. I acknowledge, however, that the narratives of the UCCO leadership submerges the stories or voices of individual officers and present a unified voice. I also consider the activities of the UCCO since Smith's death, specifically the establishment of a Global Agreement with the Correctional Service of Canada (CSC), and their demands for changes to the Canada Labour Code with regard to dangerous working conditions. Finally, while this article is not about the broader struggles of trade unions in the context of neoliberal austerity, I do suggest we need to question the place of correctional officer unions in the trade union movement. By looking to the important work of labour historians and critical prison scholars in the United States we can begin to challenge the fragmenting of the working class through tough-on-crime politics, as a part of Canada's own neoliberal agenda. A re-reading of the narratives of distress for those who have lived, died, and worked in administrative segregation is an abolitionist moment that points to the failure of reform and the need to abandon the prison.

\section{Methodology}

In an effort to address an analytical and empirical gap in Canadian prison scholarship, this article presents a content analysis of select public digital reports and news stories between 2005 and 2015. These documents were located on the UCCO website using a search for all embedded reports concerning Ashley Smith or federally sentenced women. This search resulted in three reports authored by the UCCO Executive Committee, the published findings of a workplace survey commissioned by the CSN, and the Global Agreement between CSC and the UCCO. ${ }^{2}$ Each of these reports was coded for descriptions of working conditions, job stress, and female offenders. The findings of my analysis of these documents are presented in the context of key events surrounding the use of segregation in federal women's prisons: the implementation of Creating Choices (Government of Canada 1991) and the findings of the Arbour Commission of Inquiry (1996). I also consider

\footnotetext{
A New National Strategy for High Risk Women (August 2005); Rewards and Consequences: A Correctional Service for the $21^{\text {st }}$ Century (June 2007); A Rush to Judgement: A report of the death in custody of Ashley Smith an inmate at Grand Valley Institution (2008); Correctional Officers and Their Working Conditions (2003); and the Global Agreement Between the Correctional Services Canada (CSC) and the Union of Canadian Correctional Officers - Syndicat des Agent Correctionnels du Canada - CSN (UCCO-SACC-CSN (2013).
} 
the neo-liberal backdrop of the UCCO's strained relationship with the federal government despite its law and order regime. Finally, I discuss my key findings of the UCCO documents with regards to Ashley Smith and federally sentenced women.

\section{Long-Term Confinement in Administrative Segregation Must Be Brought to an End.... (Arbour 1996)}

To understand the significance of Ashley Smith's death in a segregation cell inside Grand Valley Institution and the actions of UCCO that followed, it is important to recall the significant changes to correctional policies governing women's imprisonment in Canada that have been introduced over the past two decades. At the time of Smith's death, Grand Valley Institution (GVI) was considered a model of Canada's women-centered corrections. GVI opened in 1997, following CSC's implementation of Creating Choices: The Report of the Task Force on Federally Sentenced Women (TFFSW), commissioned by the government in 1989 to address the discriminatory treatment of women prisoners confined to the now shuttered Prison for Women in Kingston, Ontario. Creating Choices called for a radical change in correctional practices with regard to the imprisonment of federally sentenced women based on principles of empowerment to raise women's self-esteem, meaningful choices in programming, respect and dignity to cultivate self-respect and respect for others, a supportive and nurturing environment, and shared responsibility for rehabilitation (Government of Canada 1991). The TFFSW's sweeping recommendations outlined a radical departure from conventional static security practices, calling for a prison design that included no perimeter wall or gun towers, no maximum security or segregation units, cottage-like residences for women that relied on dynamic security practices, and enhanced community reintegration.

In 1992, shortly after the acceptance of the recommendations of the TFFSW, the federal government introduced new legislation-the Corrections and Conditional Release Act (CCRA) - to govern the CSC and the National Parole Board and created the Office of the Correctional Investigator, "whose primary function is to investigate and bring resolution to individual offender complaints, to review and make recommendations on the Correctional Service's policies and procedures associated with the areas of individual complaints to ensure that systemic areas of concern are identified and appropriately addressed." ${ }^{\prime 3}$ The CCRA replaced the near-century-old Penitentiaries Act and followed on the heels of case law challenging the authority of the Prison Service (as it was then) to administer inmate discipline.

The CCRA sets out principles of "safe and humane custody ... through measures ... that are limited to only what is necessary and proportionate .... And that correctional decisions are made in a forthright and fair manner, with access by an offender to an effective grievance procedure" (CCRA, c. 20) As the CCRA was being implemented at the institutional level of Commissioner's Directives and Standing Orders, and CSC began its work of establishing the new regional prisons for women, conditions inside the Prison for Women continued to spiral-especially

3 http://www.oci-bec.gc.ca/cnt/roles-eng.aspx (accessed Oct. 14 2016) 
for Aboriginal women and women who self-injured or were suicidal. Archival records of the Prison for Women show correctional officers utilized their discretionary authority to create "B range," where women labelled as "incompatibles" or "heavies" were segregated from the other range, or A wing. This practice of arbitrary detention and isolation created deep tensions and conflict between the women prisoners on the A wing and those held under stricter conditions of confinement on B range. It would seem the isolation of women in crisis was to become an entrenched practice despite the lack of legislative authority under the newly enacted CCRA to do so. The unlawful segregation of women established the preconditions for the events of April 22, 1994.

As described in the official record of the Arbour Commission of Inquiry, on that evening, a verbal altercation between six women prisoners and three correctional officers occurred as women lined up waiting for their medications to be dispensed. Prisoners became confrontational with staff, making threatening gestures. Officers used mace to regain control of the women, and locked them in segregation without access to proscribed decontamination procedures. The atmosphere in the segregation unit became highly charged as women prisoners selfharmed, and urine was thrown at some correctional staff; outside the Prison for Women, staff demonstrated against the Warden's decision to return women to the ranges, demanding that the prisoners be involuntarily transferred out of the institution. On April 26, 1994-only three years after Creating Choices was accepted by the federal government's Solicitor General-in an unprecedented display of state sanctioned violence, an all-male IERT ${ }^{4}$ was called in from Kingston Prison to conduct cell extractions and strip searches of eight women already confined to the segregation unit. Women prisoners were restrained in leg irons and body belts, and the next day they were subject to body cavity searches in segregation cells rather than in a clinical setting, while still in restraints. During this time, the prisoners were denied access to lawyers. Ultimately, some of the women were transferred to men's institutions while others were held in segregation for up to nine months (Hayman 2005). ${ }^{5}$

$4 \quad$ IERT - Institutional Emergency Response Team members are specifically trained in the use of force tactics such as cell extractions, chemical agents, strip searching, and shackling.

5 Comparative international research shows a troubling symmetry in other democratic states with regard to the systemic use of discipline (strip searching, segregation of women with histories of mental illness). In 1992, research conducted in Northern Ireland following a similar incident involving a mass forced strip searching of women prisoners by guards in full riot gear revealed women prisoners were charged with assaulting prison guards and disobeying orders when resisting strip searches. In September 2002, the Northern Ireland Human Rights Commission initiated an investigation focusing on compliance with the European Convention on Human Rights with regard to torture and degrading treatment after the deaths of several women prisoners with histories of self-injury and mental illness held in segregation cells who were forced to undergo routine strip searches (Scraton and Moore 2009). In Australia, an inquiry into the conditions of confinement in a women's prison reported that in 1995, 13,000 strip searches were conducted on a population of one hundred women; in 2002, 18,889 strip searches were performed on two hundred women (McCulloch and George 2009, 110). That inquiry reported that women confined inside the Crisis Support Unit (typically for self-injurious behaviour or suicide attempts) were stripsearched a minimum of six times per day. In another Australian study of Indigenous inmate deaths in custody, Marchetti (2012) found that women prisoners' deaths were not reported nor were gendered causes of distress considered, such as lack of access to health care, impacts of traumas, and separation from family. 
In the months that followed, leaked video footage of these events was watched by Canadians on an evening investigative journalism show, The Fifth Estate. The Solicitor General appointed a Commission of Inquiry, headed by Madam Justice Louise Arbour, to conduct an examination of the events that took place from April 24 to 26 and make recommendations based on her review of the evidence. In her final report, Arbour highlighted the complex array of Commissioner's Directives, Standing Orders, Regional instructions, and internal memos that pointed to a culture of discretion outside the statutory framework of the CCRA and the Charter of Rights and Freedoms. "Indeed, it is evident that some very important, yet essentially simple, legal principles which govern crucial aspects of the operation of the Correctional Service have become lost in a myriad of elaborate policy and regulatory provisions. It is apparent that it is not well understood within the Correctional Service that the decision to follow the law (as opposed to policy) is not a matter of discretion" (Arbour 1996, 13).

In her report, Arbour "castigated CSC for its deplorable defensive culture and showed in forensic detail how CSC chose to disregard the Rule of Law whenever it suited its purposes and had a disturbing lack of commitment to ideals of justice" (Arbour 1996, 139). For the purposes of this article, the key recommendations made by Justice Arbour are those with regards to the arbitrary use of segregation. In her final report she recommended:

(d) that the practice of long-term confinement in administrative segregation be brought to an end;

(e) that, in order to so achieve, a time limit be imposed along the following lines:

(i) if the existing statutory pre-conditions for administrative segregation are met, an inmate be segregated for a maximum of three days, as directed by the institutional head, in response to an immediate incident;

(ii) after three days, a documented review take place, if further detention in segregation is contemplated;

(iii) the administrative review specify what further period of segregation, if any, is authorized, up to a maximum of 30 days, no more than twice in a calendar year, with the effect that an inmate not be made to spend more than 60 non-consecutive days in segregation in a year;

(iv) after 30 days, or if the total days served in segregation during that year already approaches 60 , the institution be made to consider and apply other options, such as transfer, placement in a mental health unit, or other forms of intensive supervision, but involving interaction with the general population. (Arbour 1996, 135)

In short, Justice Arbour called for the end of extended periods of confinement in segregation, and an end to the discretionary authority of CSC managers and frontline officers to work outside of the legislative framework of section 31 of the CCRA. Section 31 explicitly states that administrative segregation must be used as a last resort "if there is no reasonable alternative," and reviews of an inmate's continued segregation are conducted in a "prescribed time and prescribed manner" by the Institutional Head (CCRA, c. 20). 
Despite the findings and recommendations of the Arbour Inquiry in 1996, correctional officers claimed that the implementation of Creating Choices failed to address the problem of women with histories of violence. They asserted staff were at risk of psychological and physical distress working in an environment where they had limited ability to control certain groups of women. In 1997, women classified as maximumsecurity and those with intensive mental health needs were transferred to specifically designed high security units within three federal men's prisons. By 2000, secure units were constructed in each of the new "women-centred" multi-level prisons. ${ }^{6}$ Various Correctional Bulletins were also introduced at this time to enhance levels of supervision and security, such as the Structured Living Environment for medium-security women prisoners with cognitive or mental health problems, as well as the Intensive Supervision Strategy for women designated as maximum-security who are confined to the secure units. In 2003, the Management Protocol, which was specific only to women prisoners, was introduced: it was a series of unique standing orders that singled out prisoners by CSC as high risk for escape or violence, to be held in the secure unit under extreme conditions: inmates were confined to cells twenty-three hours a day, and their movement was to be controlled through security escorts, body belts, and shackles. It would seem the CCRA-notwithstanding section 31-continued to enable the unfettered discretionary authority of the Commissioner of Corrections to allow for the establishment, at the institutional level, of the unprecedented and discriminatory control of women prisoners. As documented by the Correctional Investigator, Aboriginal women and women with severe mental health problems were over-represented in secure units as well as under the Management Protocol. Between 2001 and 2006, human rights experts and prisoner advocates such as the Canadian Association of Elizabeth Fry Societies (CAEFS), Amnesty International, the Native Women's Association of Canada (NWAC), and the Disabled Women's Network (DAWN) continued to document how CSC was operating in violation of domestic and international human rights laws (CAEFS 2003, 2005). In 2003, the Canadian Human Rights Commission (CHRC) also denounced CSC's conduct and its continued use of administrative segregation to indefinitely confine Aboriginal women and women with serious mental health needs and cognitive disabilities in maximum security units (CHRC 2003). Even the government's own Correctional Investigator, in his annual reports to the Minister of Public Safety, continued to seek compliance with recommendations of the Arbour Inquiry as well as domestic and international law:

Respecting and preserving fundamental human rights and freedoms should form the backbone of any correctional endeavour. The regular duties and functions of all correctional staff such as initiating use of force, searches, placements in segregation and transfers to higher security significantly impede and intrude upon the rights of offenders. The Correctional Service of Canada has great authority over every single aspect of the lives of offenders. For this reason, the actions of the Correctional Service of Canada must comply with the rule of law and be consistent with human rights protections afforded by law. (Correctional Investigator of Canada 2006, 5)

6 No secure units were added to the Okimaw Ochi Healing Lodge, as it is designated a medium security, whereas other regional prisons are multi-level. As a result, Aboriginal women classified as maximum security are not housed in the healing lodge. 
Another important backdrop to the increasing punitiveness of the Canadian prison system pertains to two key events in the expansion of the Canadian carceral state. The first was the striking of an independent panel in 2006 by the newly elected minority Conservative federal government to examine several aspects of CSC's operations as well as those of the National Parole Board. Its report was released in 2007 and made several recommendations that called for the transformation of the federal prison system towards regional multi-level complexes to address greater balance between static and dynamic security (Sampson et al. 2009; Head 2008 cited in Piche 2011,639). These proposed complexes were to be similar in design to the existing maximum security reception centers and regional psychiatric centers run by CSC. The UCCO's own submission to the panel, entitled "Rewards and Consequences: A Correctional Service for the $21^{\text {st }}$ Century: A Brief to the Independent Review Panel Studying the Future of Correctional Service of Canada, specifically addressed the implications of the Arbour Commission's call for the end to long-term administrative segregation as endangering the lives of correctional officers, and the ineffectiveness of the Management Protocol to properly managed high risk female offenders. In this report, the UCCO directly cites from two US reports to assert that "while there are immense differences between our two systems, the basic realities of incarceration are immutable" and "correctional officers deserve a professional status equal to that of law enforcement professionals." As I will discuss below, the drawing of parallels with the US prison system is a constant feature of the UCCO's demands for greater respect by the federal government and greater investment in higher security prisons.

The second key moment that foregrounded the actions of the UCCO was the great recession of 2007-2008, which introduced successive years of deep cuts to public services, reductions in public sector wages, and a decidedly more antagonistic relationship towards organized labour. Yet, as austerity measures were introduced by the Treasury Board, critical prison scholar Justin Piche examined CSC's annual budget documents from 2005 to 2010 and concluded "the organization's net expenditures had increased by $54 \%$... with a capital expenditures budget which included funds set aside for facility construction - that ballooned by 138.4\%" (Piche 2011, 639). This planned carceral expansion was driven by the predicted impact of proposed legislation. Bill C- $25^{8}$ called for more limits on earned remission (conditional release), and CSC officials predicted an increase of 3,400 prisoners and greater reliance on double bunking. Yet, the planned growth of federal prison populations outstripped capital spending in new prison expansion; instead federal prisons became overcrowded and programming for prisoners was clawed back. As result, institutional management turned to extended use of segregation to manage prisoners like Smith, in need of extensive mental health programming.

In sum, Smith's time in federal custody was foreshadowed by the federal government's refusal to heed warnings by oversight bodies such as the Correctional

\footnotetext{
7 "The Commission on Safety and Abuse in America's Prisons" and "Confronting Confinement" cited in UCCO-SACC-CSN 2007, 6-7.

8 http://www.lop.parl.gc.ca/About/Parliament/LegislativeSummaries/Bills_ ls.asp?ls $=\mathrm{c} 25 \& \operatorname{Parl}=40 \&$ Ses $=2$ (accessed March 26 2017)
} 
Investigator and the Canadian Human Rights Commission as to the discriminatory treatment of federally sentenced women and the worsening of conditions inside federal prisons, as well as increasingly hostile labour relations with one of its largest employee sectors: correctional officers.

\section{"Pride, Solidarity, Dignity": Union of Canadian Correctional Officers}

In 1999, federal correctional officers voted to leave the Public Service Alliance of Canada (PSAC), and became certified as the Union of Canadian Correctional Officers (UCCO). The secession of UCCO from PSAC was driven by demands for recognition of the unique working conditions faced by correctional officers more aligned with those of law enforcement and military service. This reorganization was rooted in the results of a commissioned study of correctional officers' experiences in the workplace:

The working conditions, broadly defined, comprise some important similarities with the jobs of RCMP general duty constables, including contact with the criminal justice system, response to emergency situations, violence and the exposure to danger. There are also important differences in working conditions that provide correctional officers with added challenges: the daily contact with offenders, including those who officers themselves may have reported and charged, and the risk of contracting infectious diseases. ... It is fair to say that over the years, the vast majority of correctional officers have either directly experienced or will experience a serious violent incident while on the job. And some will themselves be the target of this violence. (Joint Committee Report on Federal Correctional Officers (2000) cited in Samak 2003, 17)

In 2003, the UCCO commissioned another national survey on the quality of the institutional work environment that included officers' perceptions of their own physical, psychological, and technical ability to do their jobs. The survey represented one of the largest workplace studies focused on correctional officers in the OECD, with over 2,500 completed surveys. Those survey results showed that older male correctional officers working in multi-level security institutions report higher rates of workplace stress and psychological harassment by supervisors, yet are less likely than women officers to report harassment and are more likely to be clinically diagnosed with depression. The major cause of poor working conditions identified by respondents is the "increased levels of detention capacity, and poor quality of administration, organizational and technical supervision" (Samak 2003, 29). These survey results suggest older male officers experience a great deal of workplace stress in these multi-level environments and report these institutional settings are poorly managed and rife with harassment. A key aim of the UCCO since its inception has been the recognition of the nature of the work of correctional officers as equal to that of law enforcement and military in combat situations.

Often citing reports and studies from the United States to document the level of stress experienced by correctional officers, the UCCO highlights the levels of PTSD (post-traumatic stress disorder) (17\% of respondents) as similar to those of Vietnam veterans (Rosine 1992, 17). Through these militarized narratives of "combat fatigue," the UCCO has (mis)appropriated very different political, racial, and 
economic histories of incarceration that exist in the United States, wherein prison and police officer unions became much more politically influential during the initial phase of austerity measures under neo-liberalism, advising governments on crime bills and prison design (Gottschalk 2015; Page 2011). Much of this makes sense if we understand the prison industry complex as a necessary response to managing the new "dangerous class" - those who white working- and middle-class voters feared-but also to the well-paying secure jobs that were disappearing and were fiercely defended by organized labour.

In Canada two decades later, the ascendancy of neo-conservative federal and provincial governments did not manifest in the swelling of the prison officer rank and file, but it did increase the rates of incarceration and pre-trial detention. ${ }^{9}$ The UCCO was shut out of political decision-making regarding prison policy. As I outline below, the UCCO, in its antagonistic relationship with the Canadian state, engaged in trade union activism that endangered the lives of women prisoners. Embedded in the text of the UCCO reports to various government commissions regarding reforms to the mandate and operations of correctional institutions is a gendered narrative of public safety, dangerous work environments, and urgent reforms needed. In the next section, I highlight the chronology of reports made by the UCCO to government commissions regarding federally sentenced women.

\section{A New National Strategy for High Risk Women}

One the first reports authored by the UCCO leadership committee targeted the failure of Creating Choices to address-in their view-the increasing level of violence and mental illness amongst women prisoners. While acknowledging the lack of services for mental health and addiction in the community, in their report A New National Strategy for High Risk Women, the UCCO leadership proposed a dedicated special handling unit within each regional prison for those women labelled extremely violent, requiring more control than women held under the Management Protocol. The UCCO recommended a contained special handling unit within each prison, away from the secure units (maximum security). The UCCO describes the disruptive effect of the Protocol within the secure unit, the ineffectiveness of the Protocol in changing prisoners' behaviour, and the psychological and physical distress of frontline officers who have to work in these environments without adequate training and resources. In the text of the report, we witness the gendering of risk, but also the reframing of women prisoners' distress and resistance, as a toxic work environment that endangers frontline correctional officers. On one hand, the UCCO provides a clear critique of the current practice of segregation as inhumane and unlikely to produce the reintegration of prisoners due

Statistics Canada reported that between $2004 / 05$ and 2014/05 there was a $39 \%$ increase in the daily remand (pre-trial custody). See http://www.statcan.gc.ca/daily-quotidien/170110/ dq170110b-eng.htm. The Office of the Correctional Investigator reported that, between 2005 and 2015 , the CSC incarcerated population increased by $13.6 \%$; the number of women increased by $77.4 \%$ and men by $11.6 \%$; the number of Aboriginal prisoners increased by $52.4 \%$; and the number of black prisoners increased by $77.5 \%$. See http://www.oci-bec.gc.ca/cnt/rpt/oth-aut/othaut20150528-eng.aspx. 
to its psychological and social consequences of prolonged isolation. Yet, on the other hand, the UCCO advocates for a designated "supermax" unit for highly "disturbed" female inmates to protect its members from violence in the workplace. In the following excerpt from their report, the UCCO again erases the institutionalized violence perpetrated against women prisoners, such as the use of mace, cell extractions, and strip searches. Instead, they recast officers as the real victims of violence: "Given the increase in violent events in the institutions for women, action must be taken immediately to protect the personnel in these units. We believe that any delays in establishing such reinforced units could lead to other violent incidents initiated by these inmates whose history of violence could fill up several pages and which would thus again produce new victims amongst the CSC's personnel" (UCCO-SACC-CSN 2005, 7).

The UCCO listed the benefits of their proposed new supermax strategy as the reduction of violent incidents such as hostage taking and assaults on staff, as well as "less likel[ihood] that the personnel will suffer from burnout .... and lower risks of contamination between inmates with a "super-max" security rating and inmates with a maximum-security rating; and more administrative segregation places made available, since these cells would no longer accommodate these 'super-max' inmates" (UCCO-SACC-CSN 2005, 6). The expansion of the prison-specifically segregation-becomes legitimated through claims of harm to staff; yet the harms of institutionalized violence are erased. The counter-narrative of the effects of hyper-securitized regimes on prisoners is well documented in empirical studies yet remains unrecognized by the UCCO (Haney 2003, 2008, 2012).

\section{Rewards and Consequences: A Correctional Service for the $21^{\text {st }}$ Century}

In 2007, the federal government's Minister of Public Safety commissioned an independent review panel on the future of CSC to study and make recommendations to strengthen the capacity of CSC to ensure public safety and to identify greater cost efficiencies (Correctional Services of Canada Review Panel 2007). In its submission to the panel, the UCCO highlighted an earlier initiative within CSC-the Operational Regimes system - that was intended to redesign prisoner security classifications as determined by a prisoner's compliance with her correctional plan. The proposed regime system also called for greater use of deprivation (loss of privileges) to correct prisoner behaviour. The UCCO asserted that this regime change was necessary to address the increasing numbers of violent offenders with significant mental health disorders. Thus, the UCCO called for a change to the CCRA to amend the statutory provision that directs CSC to manage prisoners according to a least restrictive measure. ${ }^{10}$

The Operational Regimes initiative was never implemented due to the anticipated infrastructure costs. This is in sharp contrast with the US response to fiscal austerity a decade earlier, wherein prison construction exploded in tandem with

10 Section $4 \mathrm{~d}$ of the CCRA (principles) sets out that treatment is based on the least restrictive/intensive form of intervention possible; therefore inmates are to be housed in the least restrictive environment possible, with the lowest level of security required to ensure public safety. 
mass incarceration. However, the UCCO continued to call for an expanded use of segregation units in the women's regional prisons. In its submissions to the panel, the UCCO leadership referred to the violent confrontations at Prison for Women in 1994 and the untenable recommendation of the Arbour Commission to end the use of administrative segregation. The UCCO argued that, since the Arbour Commission, serious incidents such as the hostage taking of CSC personnel and inmates, severe assaults, injuries, and death threats continued in women's federal prisons. Indeed, the UCCO described the current conditions in women's prisons as "a wave of incidents that repeatedly involved a hard core of female inmates" (UCCO-SACC-CSN 2007, 39). Again, as in 2005, the UCCO recommendation to the Review Panel was the creation of "a new Special Handling Unit designed to safely accommodate female inmates who pose a greater risk than the regular maximum security offenders. In order to foster a secure and humane approach to highrisk inmates, we propose the construction of a fortified secure area in one centrally located prison for women. This area would have to be independent and separate from the currently existing segregation sector and Secure Unit" (UCCO-SACCCSN 2007, 4).

In short, the UCCO leadership continued to call for the (re)construction of a centralized super-max prison for "high risk" women. Four months after the submission of the UCCO's report to the panel, Ashley Smith died in a segregation cell at Grand Valley Institution. In the months that followed Smith's death, the UCCO continued to assert that her death could have been averted if their special handling unit proposal had been implemented, and that officers need to be protected from the psychological trauma of responding to the needs of mentally ill prisoners.

In the news accounts of Smith's death, the UCCO's statements to the press constructed two narratives: one of a crisis of managing violent mentally ill women, the other of managerial chaos inside Grand Valley Institution. Through these claims, the UCCO reproduced the necessity of the maximum-security prison, the exoneration of administrative segregation as a condition of Smith's death, but also the view that correctional officers are victims of psychological distress, similar to what Smith experienced while incarcerated; "as much as Ashley Smith is a victim in this case, our members are also victims" (Bailey 2008). Shortly after Smith's death, the UCCO staged a show of support at Grand Valley Institution for the correctional officers who were charged and suspended by CSC. Officers organized an information picket at the entrance to the institution and fundraising for their coworkers' legal costs. During these information pickets, the UCCO pointed to the systematic failure of the CSC to properly protect the safety of its frontline staff, placing officers at risk for psychological and physical harm when working in segregation. Media reports showed the UCCO leadership accusing CSC of a cover-up and scapegoating frontline officers. As recounted in this media story:

Guards from 58 federal prisons across Canada protested yesterday in a show of solidarity with three colleagues charged in the death of an inmate. About 30 members of the Union of Canadian Correctional Officers stood at the entrance of the Grand Valley Institution for Women, holding signs and displaying T-shirts calling for "truth." "The message here is the entire country is behind these members," said the union's Ontario region president, 
Jason Godin. "These are members of the community protecting the community." In a flyer distributed at the information pickets, the union repeated a position they have maintained since the charges were laid. "All seven performed their duties as trained and ordered, while some went far beyond the call of duty in trying to save the life of an inmate known ... as an exceptionally troubled young woman," it reads. "The mismanagement of the inmate and of the federally sentenced women's sector in general will also be on trial in Kitchener." Directives handed down by the commissioner of Correctional Service Canada are inconsistently applied and "micromanaged" by leadership at the country's five women's prisons, the flyer said. (Bailey, Dec. 19, 2007, updated March 14, 2009)

What is striking throughout the various narratives of the UCCO leadership is the reframing of administrative segregation as necessary to protect workers' rights to a safe workplace, rather than as a violation of prisoner rights. The conditions of confinement within the secure unit of Grand Valley Institution (i.e., isolation and deprivation) are not conceived of as lethal; rather it is the absence of effective management within that space that is said to have led to Smith's death. As expressed by Jason Godin, the National President of the union:

What she [Ashley Smith] needed was intensive support and programming, and she needed to be in a special handling unit," he said. Those recommendations were "virtually ignored." Mr. Godin blames managers in the federally sentenced women's sector for allowing "too much politics" to get in the way of badly needed services. Seven dedicated staff who did their best in untenable conditions were used as scapegoats, he says. "We're also victims in this situation. We're victims of a system that didn't take responsibility in ensuring that the proper policies, procedures and the proper environment was put into place to save Ashley Smith's life. (Bailey 2008)

In the eight months that followed Ashley Smith's death and the criminal charging of the correctional officers who witnessed her death, the Office of the Correctional Investigator (OCI) issued a report entitled A Preventable Death (Correctional Investigator of Canada 2008). In that report, the Correctional Investigator identified several individual and systemic failures that led to her death, which in many ways echoed the findings of the Arbour Inquiry in 1995. The Correctional Investigator's text focuses on the systemic disregard for the deterioration of Ashley Smith's wellbeing while she was held in long-term segregation under the most coercive conditions. As in the Arbour Inquiry ten years earlier, the OCI called for adherence to the legislative framework of the CCRA in the use of administrative segregation and placed a greater emphasis on oversight and adherence to the inmate grievance process. Rather than a need for a super maximum-security unit as proposed by the UCCO, the Correctional Investigator points to the failure of law to protect Ashley Smith's rights while incarcerated.

In an attempt to set the record straight as to what occurred in Grand Valley Institution in the weeks leading to Smith's death, the UCCO's National Executive Committee issued its own report, A Rush to Judgement: A Report on the Death Ashley Smith, an Inmate at Grand Valley Institution for Women (UCCO-SACCCSN 2008). In that report, the UCCO derides a "catastrophically dysfunctional 
management culture that pervaded GVI as well as the federally sentenced women sector of CSC" (ibid., 5). The writers go on to condemn senior management for scapegoating correctional officers amidst a chaotic environment wherein managers were obsessed over the appearance of inordinately high numbers of use-of-force incidents involving Smith. Officers-who refused to be identified in the report out of fear of retribution from senior management-claimed the real problem at Grand Valley Institution was "a lack of trained female IERT officers, and only one psychiatric centre in Canada for women" (ibid., 23)

Embedded in the text of the report, however, were a series of accounts that portrayed Smith as almost animal like in her large size (the report refers to her weight several times) and described her super humanlike strength as she destroyed "tamper-proof" fixtures in her cell. The narrative then shifts to a discussion of Smith's frequent self-asphyxiation by placing self-styled ligatures around her neck as a "choking game" - a behaviour reported amongst young offenders in custodyas a way of getting high. Union executive members who authored the report cite a media story of deaths by young people as a result of self-strangulation, suggesting Smith's self-destructive behaviour was a game, and not the result of the conditions of confinement in maximum security. Then, bizarrely, the text shifts briefly to a discussion of Smith's self-asphyxiation as a form of auto-erotic behaviour, wherein a person will cut off their air supply while masturbating. An officer is quoted as saying, "that wasn't what Ashley was doing ... I always checked to see if she had her hands beneath her gown" (UCCO-SACC-CSN 2008, 9). This voyeuristic and sexualized narrative, read alongside descriptions of Smith as monster-like in her strength and childlike in her desire to play games with staff by goading them, reframes Smith as no longer a prisoner with legal rights to safe and humane treatment. Rebecca Jaremko Bromwich examined the report as part of her larger study of the evidence heard at the Smith Inquiry, recognizing this "game-playing child" narrative used by correctional officers as reframing their carceral power over Smith to be caring and nurturing. "This game playing child figure fits with the narratives of care, supports arguments that guards were highly skilled professionals doing their best in a challenging environment, and bolsters the union's claim that a relationship of care exists between guards and inmates in CSC facilities. ... The game metaphor also bolsters the legitimacy of the guards' role and supports the implication that it is ultimately they, not management or psy-experts who have the crucial expertise as to how to deal with prisoners and manage prisons" (Jaremko Bromwich 2015, 126-27).

The text of the report moves on to describe Grand Valley Institute as an institution of escalating violence and staff endangerment. As set out above in their 2005 proposed New National Strategy for High Risk Women, wherein the UCCO calls for a special handling unit for the most violent women prisoners, in their 2008 report, the authors re-tell accounts of critical incidents involving three women. In the first narrative, "a violent altercation with an inmate known to be HIV positive exposed officers to a significant amount of blood and officers were not able to access antiretroviral medications, as legally proscribed in CSCs 'post-exposure protocol'" (UCCO-SACC-CSN 2008, 13). What remains unacknowledged in this account is the prisoner's own suffering that resulted in a significant amount of her blood loss, 
such as self-injury or a use of force, thus reframing the officers as casualties of the prison system. The second narrative is a detailed recounting of an event that took place three years earlier:

On August 22, 2005, the violence reached a new level. Armed with a metal shank and a broken mirror shard, two inmates housed in the new secure units were able to enter the prison nursing office and take two hostages, a nurse and a behaviour counsellor. The hostages were strapped to a chair with gauze, one of them with a belt tightened around her neck. During the three-hour ordeal, the hostages were force-fed anti-psychotic medication while their attackers threatened to slash their throats and gouge out their eyes. One woman was cut with the mirror, punched in the face and burned with a lit cigarette to the arm, shoulder and armpit. The two were finally released in return for Pepsis and cigarettes. The leader in the attack had demanded to be taken off the restrictive management protocol for problem inmates, a status she had earned during a long series of violent, sadistic incidents. This woman would become one of Ashley Smith's best friends in the short time Smith lived in Grand Valley's secure unit two years later. (UCCOSACC-CSN 2008, 13)

Although the purpose of the 2008 UCCO report is to counter the findings of the Correctional Investigator's claim that Smith's death was preventable if the rule of law governing segregation was followed, the text of the UCCO document moves beyond the frame of her death. The narrative establishes the sadistic violence of federally sentenced women and the immutable necessity of deeper carceral control to protect workers. Upon a closer reading, however, the account of the critical incident shows the two women were responding to the effects of being held on Management Protocol, using similar tactics they had experienced at the hands of officers including being forcibly injected for sedation using the anti-psychotic drug Seroquel and physical restraints. It was reported later in the Smith Inquiry that such tactics were a common practice in women's prisons' secure units to immobilize highly agitated and defiant prisoners (Kilty 2014). It would seem that the UCCO recognizes the currency of depicting women prisoners as either monsters, impulsive children, or predators deserving of isolation.

\section{The Paradox of Correctional Officer Unions as Social Justice Advocates}

In the years following Smith's death and the conclusion of the Coroner's Inquiry, the UCCO turned its sights onto the federal election in 2015. The UCCO leadership aggressively targeted the sitting Conservative Party-specifically then Prime Minister Stephen Harper and the head of the Treasury Board, Tony Clement-by staging public events such as attending a Conservative party convention in Calgary, Alberta, in October 2013. In this excerpt taken from the UCCO newsletter Vigilance, the union sets out a bizarre account of its performance at the convention, intended to educate politicians and delegates on their working conditions:

On October 31 and November $1^{\text {st }}$, 2013, UCCO-SACC-CSN members hosted a hospitality suite in Calgary's downtown Marriott Hotel, where many Conservative delegates were staying and various cabinet ministers hosted raucous parties. Many party members and MPs visited our dynamic 
space, filled with large vertical banners explaining how union action helped protect correctional officers-and the Canadian public. Our traditional shank kits were ever-popular conversation starters. A video on the need for a Blood Samples Act played in one corner while a detector dog handler drew constant attention. Our mascot Yourie was a big draw for children and tourists outside the hotel. Finally, the debut of our life-sized replica of a doublebunked prison cell created equal parts of fascination and consternation among those with the courage to step inside with one of our burly "inmates." (UCCOSACC-CSN, 2014, emphasis added)

This text illuminates the erasure of class consciousness amongst prison officers and the criminalized working class that are kept locked up in these double-bunked prison cells. At the same time, the burly inmate is dehumanized as the "criminalized other" (Garland 1996, 46), marked as "diseased, incapable of self-regulation, inherently dangerous, and bear[ing] little resemblance to us" (Hannah-Moffat 2000, 526). The intersection of labour studies and cultural analysis of punishment brings into focus the material and ideological impacts of neoliberal carceralism upon the waged prison worker.

Paradoxically, in this same issue of the newsletter, the UCCO leadership reported on attending the "Forum on Common Causes" along with social justice and environmental activists such as Maude Barlow-National Chairperson of the Council for Canadians; labour economist Jim Stanford of Canada's largest private sector union, Unifor; and David Suzuki-a world recognized environmental scientist and activist. Even more striking was the image of the "Raging Grannies" used next to the published article, suggesting political alliances with feminist-inspired activists. ${ }^{11}$

As described earlier in this article, the UCCO has repeatedly called for greater protection as workers against "offenders" who are contaminated with infectious diseases and who are violent, placing correctional officers at risk. For example, in 2014, the federal Conservative government introduced Bill C-4-an omnibus bill of legislation that included changes to the Canada Labour Code, specifically requiring all rights-based claims, such as refusing to work or seeking compensation for workplace-related injuries, to be adjudicated by health and safety officers who were named by the Treasury Board. As well, Bill C-4 narrowed the definition of "danger" in the workplace to mean "any hazard, condition or activity that could reasonably be expected to be an imminent or serious threat to the life or health of a person exposed to it." The UCCO condemned the federal government for watering down the definition of a dangerous workplace by introducing the word "imminent" rather than "potential" danger, and for excluding a person as a potential hazard or condition that could be an imminent or serious threat to the life or health of a worker. The union leadership argued, in its negotiations, that inmates pose the greatest workplace danger to correctional officers: "UCCO is the most active union with regards to successful complaints in the federal public service that cited the dangerous work provision in the labour code" (UCCO-SACC-CSN 2014, 7).

11 The Raging Grannies first organized in Victoria, British Columbia, in 1987 to protest against "nuclear submarines, uranium mining, nuclear power, militarism, racism, clear-cut logging, and corporate greed” http://www.vcn.bc.ca/ragigran/. 
For example, in their most recent labour contract, CSC and the UCCO-SACC entered into a Global Agreement to provide clarification on certain provisions of the collective agreement. In that document, CSC and the UCCO set out principles for security escorts with female inmates, which are not applied to the escorts of male inmates. These principles are:

6. Before each escort of a female inmate with a current classification of maximum or medium security, a standardized risk assessment shall be completed seventy-two (72) hours prior to the escort. The Correctional Officer(s)/ Primary Worker(s) escorting the inmate shall be provided with a copy of the risk assessment.

7. The assessment will consider the level of supervision and the security equipment which should be used during the escort, based on an objective assessment of risk, including:

a) the inmate's physical and mental health;

b) the inmate's demonstrated behaviour and characteristics;

c) the purpose and destination of the escort, mode of travel and time in transit;

d) intelligence information. (CSC 2011, 13)

In this text we witness the gendering of risk in the context of labour agreements between correctional officers and the state-demonstrating the transcendence of risk logics from segregation cells to escorts into the community for purposes of rehabilitation and release planning. Women prisoners are continually returned to the reified form of the feebleminded yet potentially dangerous-more so than male prisoners. Instead, the purpose for women's escorts must be justified and their behavioural characteristics acceptable. The text of the Global Agreement, along with the various publications of the UCCO with regard to the punitive treatment of federally sentenced women, echoes the anti-feminist backlash that was unleashed in the days following the release of the Fifth Estate video as well as the Arbour Inquiry that called for an end to long-term segregation. Dell, Filmore, and Kilty (2009) assert that CSC's punitive treatment of women prisoners, especially those who self-harm or are violent, is rooted in a misogynistic ideology that locates women as attention-seeking, manipulative, and even temptresses in their behaviour towards staff.

\section{Conclusion}

This article has examined how the UCCO viewed the life and death of Ashley Smith. Since the findings of the Coroner's Inquiry into the conditions of Ashley Smith's death, and the 104 recommendations made by that jury to prevent similar tragedies in the future, the UCCO has broadened its campaign for greater use of segregation and coercive control of women prisoners. As a member of a trade union labour body that challenges unfair and unequal treatment of workers by employers and the state, the UCCO's demand for greater carceral control of Aboriginal women and women with significant mental health needs raises important questions about the place of correctional officer unions in the Canadian trade union movement. Future studies should explore the relationship between the CSN 
as a labour body and the UCCO: how is the carceral treatment of racialized, colonized, and exploited women reconciled with working-class politics? The place of organized labour in the Canadian carceral state remains a relative lacuna in critical prison scholarship; systematic study of the attitudes and beliefs of the UCCO leadership and those of the CSN is needed.

Finally, the tragedy of Smith's death reveals the "violence of incarceration" (Scraton and McCulloch 2009), the irrationality of the prison for those who are confined to it, and waged labourers of the carceral state. Yet, prison workers have agency to challenge the brutalizing working conditions of confinement that are also their working conditions. How is the death of Ashley Smith not read as an abolitionist moment in the history of prison reform in Canada? It would seem that the consciousness of waged workers such as the union leadership of the UCCOSACC has been able to reconcile the contradictions between the ruinous conservative policies that simultaneously created their working conditions and the gendered conditions of endangerment for women living with mental illness that are incarcerated in Canadian jails and prisons.

\section{References}

Arbour, The Honourable Justice Louise (Commissioner). 1996. The Commission of Inquiry into Certain Events at the Prison for Women in Kingston. Ottawa: Solicitor General.

Bailey, S. 2009. Picket support prison staff facing charges. The Globe and Mail, Dec. 19, 2007, updated Mar. 14, 2009. http://www.theglobeandmail.com/news/national/picketssupport-prison-staff-facing-charges/article699944/

_. 2008. Teen's death was preventable: Prison Watchdog. The Globe and Mail, June 24. http://www.theglobeandmail.com/news/national/teens-death-was-preventable-prisonwatchdog/article18451989/

Blankenship, S. 2005. Revisiting the democratic possibilities of prisoners' labor unions. In Crime and Punishment: Perspectives from the Humanities. Studies in Law, Politics and Society, vol. 37, 241-65. ed. Austin Sarat. Bingley, UK: Emerald Publishing.

Canadian Association of Elizabeth Fry Societies. 2003. Submission of the Canadian Association of Elizabeth Fry Societies to the United Nations Human Rights Commissioner for the Special Report on the Discrimination on the Basis of Sex, Race, and Disability Faced by Federally Sentenced Women. Ottawa: CAEFS.

Canadian Association of Elizabeth Fry of Societies. 2005. Submission of the Canadian Association of Elizabeth Fry Societies to the United Nations Human Rights Committee Examining Canada's $4^{\text {th }}$ and $5^{\text {th }}$ Reports Regarding the Conventions Against Torture. Ottawa: CAEFS.

Canadian Human Rights Commission. 2003. Protecting Their Rights: A Systemic Review of Human Rights in Correctional Services for Federally Sentenced Women. Ottawa: Canadian Human Rights Commission.

Correctional Investigator of Canada. 2006. Annual Report of the Correctional Investigator 2004-2005. Ottawa: Office of the Correctional Investigator. Last modified November 15 http://www.oci-bec.gc.ca/cnt/rpt/pdf/annrpt/annrpt20042005-eng.pdf

—. 2008. A Preventable Death by Howard Sapers. Ottawa: Office of the Correctional Investigator.

Correctional Services of Canada. 2011. Global Agreement between CSC and UCCO-SACCCSN. Ottawa: Correctional Service Canada.

Correctional Service of Canada Review Panel. 2007. A Roadmap to Strengthening Public Safety. Ottawa: Correctional Service Canada. 
Dell, C. A., C. Fillmore, and J. Kilty. 2009. Looking back 10 years after the Arbour Inquiry: Ideology, policy, practice and federal female prisoners. The Prison Journal 893: 286-308.

Ellis, D. 1979. The prison guard as careral luddite: A critical review of the MacGuigan Report on the Penitentiary System in Canada. Canadian Journal of Sociology 4 (1): 43-64.

Garland, D. 1996. The Culture of Control: Crime and social order in contemporary society. Oxford: Oxford University Press.

Gottschalk, M. 2015. Caught: The Prison State and the Lockdown of American Politics. Princeton: Princeton University Press.

Government of Canada. 1991. Creating Choices: The Report of the Task Force on Federally Sentenced Women. Ottawa: Correctional Service Canada.

Hannah-Moffat, K. 2000. Prisons that empower: Neoliberal governance in Canadian women's prisons. British Journal of Criminology 40: 510-31.

Haney, C. 2003. Mental health issues in long-term solitary and supermax confinement. Crime and Delinquency 49 (1): 124-56.

-2008. A culture of harm: Taming the dynamics of cruelty in supermax prison. Criminal Justice and Behaviour 35 (8): 956-84.

- 2012. Prison effects in the era of mass-incarceration. Prison Journal 1-24, doi: $10.1177 / 0032885512448604$.

Hayman, S. 2005. Imprisoning Our Sisters: The New Federal Women's Prisons in Canada. Montreal: McGill Queens University Press.

Jarmeko Bromwich, R. 2015. Looking for Ashley: Re-Reading what the Smith case reveals about the governance of girls, mothers, and families in Canada. Toronto: Demeter Press.

Kilgore, J. 2013. Mass-incarceration and working class interests: Which side are the unions on? Labour Studies Journal 37 (4): 356-72.

Kilty, J. 2014. Watchdog investigates anti-psychotic drug used as sleeping aid to control prisoners. The Globe and Mail. April 14. http://www.theglobeandmail.com/news/watchdoginvestigates-antipsychotic-drug-used-as-sleeping-aid-to-control-prisoners/ article18000326/

Marchetti, E. 2012. Victims or offenders? Who were the 11 Indigenous female prisoners who died in custody and were investigated by the Australian Royal Commission into Aboriginal Deaths in Custody? International Review of Victimology 19 (1): 37-49.

McCulloch, J., and A. George. 2009. Naked power: Strip searching in women's prisons. In The Violence of Incarceration, ed. Phil Scraton and Jude McCulloch, 107-123. London: Routledge.

Page, J. 2011. The toughest beat: Politics, punishment, and the prison officers' union of California. Oxford: Oxford University Press.

Piche, J. 2011. Going public: Accessing data, contesting information blockades. Canadian Journal of Law and Society 26 (3): 635-643.

Preville, Marie-Josee, and Pierre Dumont. 2005. A New National Strategy for High Risk Women. Kingston: UCCO-SACC-CSN.

Rosine, L. 1992. Exposure to critical incidents: What are the effects on Canadian correctional officers? Pleins faux le personnel 4, SCC. (http://www.csc-scc.gc.ca/text/pblct/forum/ e04/e041m_e.shtml)

Samak, Q. 2003. Correctional Officers of CSC and Their Working Conditions: A QuestionnaireBased Study. Prevention Group (Health-Safety-Environment) CSN Labour Relations Department.

Sampson, R., S. Gascon, I. Glen, Chief Louie Clarence, and S. Rosenfeldt. 2007. A Roadmap to Strengthening Public Safety: Report of the Correctional Service of Canada Review Panel. Ottawa: Minister of Public Works and Government Services Canada. 
Scraton, P., and J. McCulloch, eds. 2009. The Violence of Incarceration. London: Routledge.

Scraton, P., and L. Moore. 2009. The imprisonment of women and girls in the north of Ireland: A continuum of violence. In The Violence of Incarceration, ed. Phil Scraton and Jude McCulloch, 124-44. London: Routledge.

Thompson, H. A. 2016. Blood in the Water: The Attica Prison Uprising of 1971 and its Legacy. New York: Penguin Random House.

- 2011. Rethinking working class struggles through the lens of the carceral state: Towards a labour history of guards and inmates. Labour Studies in Working Class History of the Americas 8 (3): 15-45.

UCCO-SACC-CSN National Executive Committee. 2007. Rewards and Consequences: A Correctional Service for the $21^{\text {st }}$ Century: A Brief to the Independent Review Panel Studying the Future of Correctional Service of Canada. http://ucco-sacc-csn.ca/wpcontent/uploads/2015/11/2007-06-Rewards-and-Consequences.pdf

-2008. A Rush to Judgement: A Report on the Death Ashley Smith, An Inmate at Grand Valley Institution for Women.

UCCO-SACC-CSN. 2014. Vigilance. Last modified November 16. http://ucco-sacc-csn.ca/ wp-content/uploads/2015/06/Vigilance-Magazine-Summer-2014.pdf

Wacquant, L. 2014. The global firestorm of law and order: On punishment and neoliberalism. Thesis Eleven 122 (1): 72-88.

Zimmer, L., and J. Jacobs. 1981. Challenging the Taylor Law: Prison guards on strike. Industrial and Labor Relations Review 34, no. 4 (19): 532-44.

Zinn, H. 2003. A People's History of the United States. New York: HarperCollins.

\section{Legislation Cited}

Corrections and Conditional Release Act (S.C. 1992, c.20) http://laws-lois.justice.gc.ca/eng/ acts/C-44.6/page-2.html\#h-4

Gillian Balfour

Associate Professor

Department of Sociology

Trent University

gillianbalfour@trentu.ca 